Southern Illinois University Carbondale

OpenSIUC

Publications

Department of Zoology

$1-2011$

\title{
Survival, Habitat Selection, and Body Condition of the Woodchuck (Marmota monax) across an Urban-rural Gradient
}

\author{
Eric C. Hellgren \\ Southern Illinois University Carbondale, hellgren@ufl.edu \\ Timothy J. Polnaszek \\ University of Minnesota
}

Follow this and additional works at: http://opensiuc.lib.siu.edu/zool_pubs

Published in American Midland Naturalist, Vol. 165, No. 1 (January 2011) at doi: 10.1674/

0003-0031-165.1.150

\section{Recommended Citation}

Hellgren, Eric C. and Polnaszek, Timothy J. "Survival, Habitat Selection, and Body Condition of the Woodchuck (Marmota monax) across an Urban-rural Gradient." (Jan 2011).

This Article is brought to you for free and open access by the Department of Zoology at OpenSIUC. It has been accepted for inclusion in Publications by an authorized administrator of OpenSIUC. For more information, please contact opensiuc@lib.siu.edu. 


\title{
Survival, Habitat Selection, and Body Condition of the Woodchuck (Marmota monax) across an Urban-Rural Gradient
}

\author{
ERIC C. HELLGREN ${ }^{1}$ AND TIMOTHY J. POLNASZEK ${ }^{2}$ \\ Cooperative Wildlife Research Laboratory and Department of Zoology, Southern Illinois University Carbondale, \\ Carbondale 62901
}

\begin{abstract}
Urban-adapter species facultatively exploit human-subsidized resources in the urban and suburban matrix. We used the woodchuck (Marmota monax) to study how aspects of autecology in an urban-adapter can vary across a gradient of urbanization. We captured and monitored woodchucks by radiotelemetry in southern Illinois from summer 2007 to spring 2009. We captured 47 woodchucks (19 adults, 19 yearlings, 8 young-of-the-year) during the active seasons, and implanted radiotransmitters in 17 adults and 3 yearlings ( $13 \mathrm{~F}, 7 \mathrm{M})$. Overall annual survival was estimated to be $0.76 \pm 0.12$, with three confirmed mortalities during the study period. Survival and home-range size did not vary by $\%$ urban landcover in a buffer surrounding an individual's home range. Habitat-selection analyses indicated that rural edge was the highest-ranked habitat at the home-range scale, whereas urban cover (specifically, developed areas with human structures) was most highly ranked at the withinhome-range scale. Body condition was negatively related to \% urban landcover. Overall, our findings indicated no clear relationship between woodchuck ecology and urbanization level within our study area. However, our data on body condition and adipose composition, although preliminary, suggested a possible mechanism for variation in overwinter survival across the urban-rural gradient.
\end{abstract}

\section{INTRODUCTION}

Anthropogenic effects on landscapes produce major changes in the composition of plant and animal communities as well as the structure and function of ecosystems. Urban development, arguably the longest-lasting and most influential anthropogenic effect on native ecosystems, causes extensive local extirpations of native species and provides opportunities for invasions of nonnative species (McKinney, 2002). However, animal species vary widely in their response to urbanization, with many native species successfully occurring in urban environments. Two groups of species, identified as urban adapters and urban exploiters (terms attributed to R. B. Blair in McKinney, 2002), facultatively and obligatively, respectively, use human-subsidized resources to exist in urban environments.

Urban adapters are species that are commonly found in the matrix of habitats (residential yards, undeveloped lots, maintained greenspaces, remnant woodlots, etc.) found in urban and suburban landscapes (McKinney, 2002). Examples of common urban-adapting mammals include fossorial species such as moles (family Talpidae) and ground- and treedwelling squirrels (family Sciuridae), as well as a variety of medium-sized (5-15 kg) to large (>20 kg) carnivores (Randa and Yunger, 2006; Gehrt et al., 2009). These species can exploit the rich resources associated with human-subsidized habitats.

The woodchuck (Marmota monax) serves as a model urban-adapter. This species thrives at the interface of forests and openlands, which include old fields, pastures and residential lawns (Armitage, 2003). They select woodland edges and brushy fencerows (Swihart, 1992), as well as a variety of human structures (e.g., houses, garages, sheds, outbuildings, culverts and earthen dams) for burrow locations. Conversely, woodchucks negatively affect humans

\footnotetext{
${ }^{1}$ Corresponding author: Telephone: (618) 536-7766; FAX: (618) 453-6944; e-mail: hellgren@siu.edu.

${ }^{2}$ Department of Ecology, Evolution and Behavior, University of Minnesota, St. Paul, Minnesota 55108
} 
economically in a variety of ways in both residential and agricultural settings. In and around human dwellings, woodchucks can damage garden crops and ornamental plants, gnaw through floors, and produce other minor nuisance problems (reviewed in Armitage, 2003). In agricultural areas, they damage orchard trees (Swihart and Picone, 1994) and a variety of crops including small grains, hay grasses and beans (Armitage, 2003). Management usually involves exclusion (mechanical or chemical), trapping or lethal control. Finally, woodchucks provide recreational opportunities through regulated trapping and hunting seasons.

A basic question regarding the ecology of urban-adapter species revolves around whether they are synanthropes (i.e., species that benefit from their contact with human activities) or, alternatively, they are not synanthropes but nevertheless occur in urban environments by avoiding human-dominated areas (Gehrt et al., 2009). We studied a woodchuck population occurring across an urban-rural gradient to explore these contrasting alternatives. Our objectives were to estimate survival rates, estimate home-range size, determine habitat selection and document variation in body condition and adipose tissue of woodchucks. Under the assumption that woodchucks benefit from human resources, we predicted that we would observe higher survival rates, smaller home-range sizes and improved body condition in woodchucks as functions of increased urbanization.

\section{Materials ANd Methods}

Study area.-We conducted field work in Jackson, Union and Williamson counties in Southern Illinois and centered our effort in and around the greater Carbondale (population ca. 26,$000 ; 37^{\circ} 43^{\prime} \mathrm{N}$ and $89^{\circ} 13^{\prime} \mathrm{W}$ ) area. These counties contain a wide range of urban, agricultural, exurban, old field and forested areas. Woodchucks and their burrows were located in these habitat types except interior forests of the Shawnee National Forest. Jackson, Union and Williamson counties of Southern Illinois experience hot, wet summers (mean Jul. temp. $25 \mathrm{C}$ ) and mild winters (mean Jan. temp. -1 C), averaging $117 \mathrm{~cm}$ of annual precipitation (Midwest Regional Climate Center, 1971-2000).

Capture, handling, and monitoring.-We trapped woodchucks with wire-mesh Tomahawk traps ( 25 by 30 by $81 \mathrm{~cm}$; Tomahawk Live Trap Company, Tomahawk, Wisconsin) baited with apples, peanut butter, sweet potatoes and carrots and set near burrow entrances. Captured animals were anesthetized with intramuscular injections of ketamine hydrochloride and xylazine hydrochloride at doses of $15 \mathrm{mg} / \mathrm{kg}$ and $10 \mathrm{mg} / \mathrm{kg}$, respectively. All individuals were weighed, sexed, aged (young-of-year, yearling, adult; Davis, 1964) and assessed for reproductive status. Reproductive maturity of males was determined by the presence of scrotal testes (Swihart, 1992). Reproductive status of females (maturity, pregnancy and lactation) was assessed by palpation and condition of nipples (Snyder and Christian, 1960).

Adult and yearling woodchucks were implanted with an intraperitoneal radiotransmitter (Model M1240, Advanced Telemetry Systems, Isanti, Minnesota). In 2008, we also implanted Thermochron ibuttons (Maxim/Dallas Semiconductor), which recorded core body temperature over 30 min intervals. Radiotransmitters and iButtons were implanted in the surgery room of the Laboratory Animal Program or the Wildlife Annex building at SIUCarbondale as per Beiglbock and Zenker (2003). Briefly, an incision was made along the ventral midline caudal to the caudal end of the sternum. After dissection of the subcutaneous tissue, a smaller incision was made to open the abdominal cavity. The transmitter and iButton were inserted into the abdominal cavity. Incisions were closed with absorbable sutures. Animals were monitored until fully mobile $(<12 \mathrm{~h})$, then released at the site of capture. 
Telemetered individuals were monitored 2-7 times weekly throughout the active season (approximately Mar. to Nov.), with a minimum period of $18 \mathrm{~h}$ between locations. Tracking was reduced during the winter months due to overall inactivity of woodchucks. Only one individual changed burrow location during the winter months. When transmitters become inactive for $>12 \mathrm{~h}$, the pulse frequency on the transmitter changed from $55 \mathrm{ppm}$ to $110 \mathrm{ppm}$. This change in frequency typically indicates mortality. However, hibernating woodchucks may be inactive for $>12 \mathrm{~h}$, and telemetric monitoring therefore may suggest mortality. During hibernation, mortality dates can be confirmed by iButtons when animal core temperatures remain at ambient temperatures for an extended period that is not consistent with cycles of body temperatures during torpor. iButtons were retrieved by capture and euthanasia of monitored woodchucks in early spring after emergence from hibernation. Data from retrieved iButtons were used to determine dates of emergence from hibernation but otherwise are not presented in this manuscript.

Habitat selection.-We defined home ranges for each individual from the radiolocations of each individual. Geographic coordinates of each location were determined with a handheld Global Positioning System (GPS) unit (eTrex Summit, Garmin, Olathe, Kansas). We used the Home Range Extension (Hooge and Eichenlaub, 1997) for ArcView 3.2 geographical information systems software (Environmental Systems Research Institue, Redlands, California) to estimate and plot $95 \%$ minimum convex polygon (MCP) home-range estimates. Kernel methods have a number of advantages over MCPs for understanding space use of animals within their home range (Kernohan et al., 2001), but we were not focused on detailed use of the home range in this paper. We used the MCP method to provide an unbiased estimate of space available to monitored woodchucks. Given that woodchuck space use is focused around burrow systems, kernel estimators would produce home ranges shaped by these foci of use and, therefore, confound availability with use. Also, we used the MCP estimator for direct comparisons to previous estimates of woodchuck range size in the literature.

We classified landcover as urban or rural for habitat analysis and hand-digitized landcover types using an aerial photo of the study area. Urban landcover was further broken down into four categories: developed (structures, roads, parking lots etc.), urban open (maintained open areas surrounded by developed land cover), urban grassland (grassland or unmaintained open areas surrounded by developed landcover) and urban forest (forested areas surrounded by developed landcover). Rural landcover was subdivided into three categories: rural forest, rural open/grassland and rural agriculture. Woodchucks typically inhabit forest edges, occupying areas of open habitats-such as pastures, old fields and agricultural fields-juxtaposed to forested habitats (Armitage, 2003). Therefore, we defined woodland edge habitats as $20-\mathrm{m}$ strips of habitat $(10 \mathrm{~m}$ on each side) centered on hard boundaries between forest landcover and all other landcover types. Edge habitat was divided into urban edge and rural edge. Coordinates for woodchuck locations were overlaid on the landcover map. We used burrow distribution and telemetry observations to characterize habitat use (Swihart, 1992).

Body condition analysis. - We estimated body composition from captured and euthanized radiotransmittered individuals $(n=9)$ at the end of the hibernation period in spring 2009 . We calculated body condition index (BCI) as body mass divided by length cubed for all captured individuals. Kidney fat, expressed as a percent of total kidney weight and termed kidney fat index (KFI; Riney, 1955), can be used as an indicator of overall body fat and the condition of an individual. We estimated KFI in each euthanized woodchuck.

We collected 2-g samples of muscle and abdominal adipose (fat) tissue from eight woodchucks, placed the samples in whirlpak bags, and froze them at $-70 \mathrm{C}$ until lipid 
analysis. Prior to lipid extraction, muscle samples were freeze-dried and pulverized; adipose samples were extracted intact. Tissue samples were extracted using a modified Folch (chloroform/methanol) extraction (Folch et al., 1957), and the resultant crude lipid samples were subjected to acid-catalyzed transmethylation performed overnight at $50 \mathrm{C}$ as described previously by Christie (1982). The resultant fatty acid methyl esters (FAME) were separated using a Shimadzu GC-17A gas chromatograph (Shimadzu Scientific Instruments, Kyoto, Japan) equipped with a flame ionization detector (FID) fitted with a permanently bonded polyethylene glycol, fused silica capillary column (Omegawax 250, $30 \mathrm{~m} \times 0.25 \mathrm{~mm}$ i.d., $0.25 \mu \mathrm{m}$ film). The injection volume was $1.0 \mu \mathrm{L}$, helium was the carrier gas $(30 \mathrm{~cm} / \mathrm{s}$, $205 \mathrm{C})$, and the injector temperature was $250 \mathrm{C}$. A split injection technique (100:1) was used, and the temperature program was as follows: $50 \mathrm{C}$ held for $2 \mathrm{~min}$, increased to $220 \mathrm{C}$ at $4 \mathrm{C} / \mathrm{min}$ and held at $220 \mathrm{C}$ for $15 \mathrm{~min}$. Individual FAME were identified by reference to external standards (Supelco 37 Component FAME Mix, PUFA-1 (PUFA = polyunsaturated fatty acids), and PUFA-3; Supelco, Bellefonte, PA, USA). All solvents used were of High Performance Liquid Chromatography (HPLC) grade and obtained from Sigma Diagnostics Inc. (St. Louis, Missouri, USA).

Data analysis. - The percentage of area in a 500-m-radius buffer around each home range that comprised urban landcover (urban landcover is described above) was used to place each woodchuck along an urbanization gradient. We estimated survival rates of telemetered woodchucks with the known-fates model in program MARK (White and Burnham, 1999) and used model selection to assess sex, season (active season: 1 Apr.-30 Sept.; inactive season: 1 Oct.31 Mar.) and sex*season effects on survival. We also incorporated the $\%$ of urban landcover in a 500-m-radius buffer around original capture location of the monitored woodchuck as a covariate in our model selection. The known-fates model is an adaptation of the Kaplan-Meier Limit Estimator (K-MLE) with the staggered-entry design (Pollock et al., 1989), which allows newly telemetered individuals to be added to the sample at any time. We formatted each encounter history into monthly intervals starting with 1 Apr. and coded each encounter as live, dead or censored. Telemetered individuals were considered censored if radio contact was lost.

Habitat selection was assessed by compositional analysis (Aebischer et al., 1993). Compositional analysis uses log-ratios of use and availability in a multivariate approach to determine selection among habitats. It alleviates some of the statistical problems of other methods of habitat selection. Individual animals were considered as replicates. Of the 16 monitored animals, only one pair had slight range overlap during the study. Based on published work, we predicted that woodchuck selected edge habitats (Swihart, 1992; Armitage, 2003). We conducted analyses at two scales (second- and third-order; Johnson, 1980) in a hierarchical manner. These two analyses represent selection at the scale of the home range (second-order) and at the scale of specific habitat types within the home range (third-order). To examine second-order habitat selection, we compared landcover composition in home ranges (used habitat) to the landcover composition in a 500-m buffer around the center point of the individual's home range (available habitat). A buffer of $500 \mathrm{~m}$ was chosen based on the maximum movement $(470 \mathrm{~m})$ of an individual woodchuck, and thus relevant to selection of home ranges by dispersing woodchucks. We also assessed habitat selection at the third-order level. For this analysis, the landcover composition of the home range was considered available habitat for a given individual and the specific types used by that individual were considered as used habitat. Hierarchically, we examined selection at three levels: (a) all nine landcover categories described above; (b) a reduced set of four categories (pooled urban types, pooled rural types, urban edge and rural edge); and (c) edge vs. non-edge. 
TABLE 1.-Survival modeling for woodchucks monitored by radiotelemetry in southern Illinois, 20082009

\begin{tabular}{lcccccc}
\hline \hline \multicolumn{1}{c}{ Model } & AICc & $\Delta$ AICc & $w_{\text {i }}$ & Likelihood & K & Deviance \\
\hline sex & 28.67 & 0.00 & 0.46 & 1.00 & 1 & 26.64 \\
\{sex*season\} & 30.04 & 1.37 & 0.19 & 0.50 & 2 & 25.94 \\
$\{$ constant\} & 30.62 & 1.95 & 0.14 & 0.38 & 1 & 28.59 \\
\{sex * urban\} & 30.71 & 2.04 & 0.14 & 0.36 & 2 & 26.61 \\
\{season\} & 31.93 & 3.26 & 0.07 & 0.20 & 2 & 27.83 \\
\{sex*season*urban\} & 32.13 & 3.46 & 0.06 & 0.18 & 3 & 25.94 \\
\hline
\end{tabular}

We assessed metrics of body condition (BCI, KFI) along the urbanization gradient by regressing woodchuck condition on percent urban landcover within that woodchuck's buffered home range. Fatty acid data were assessed for normality with the Shapiro-Wilks test. The distribution of $81 \%$ (47 of 58) of the fatty acid-sample (muscle or fat) combination data sets did not differ $(\mathrm{P}>0.05)$ from normality. Variables that did differ from normality composed $<0.2 \%$ of total fatty acid composition. Therefore, we compared composition of adipose and muscle samples for each fatty acid by ANOVA nested by individual. We also compared fatty acid composition between urban $(>50 \%$ urban landcover in buffered home range) and rural ( $<50 \%$ urban landcover) woodchucks by ANOVA for each sample type (fat or muscle). We set the $\alpha$-level for individual comparisons at $\mathrm{P}=0.05$, and report values for $0.05<\mathrm{P}<0.10$ as results of potential reader interest. The Bonferroni-corrected experimentwise $\alpha$-level for fatty acid analyses was $\mathrm{P}=0.0017$ due to multiple comparisons. We conducted all statistical analyses using SAS software (SAS/STAT Version 9.2; SAS Institute, Cary, North Carolina).

\section{RESUlts}

We captured six woodchucks ( 2 adult females, 3 adult males, 1 yearling) during Jun.-Aug. 2007 in 196 trapnights, and 41 woodchucks (10 adult females, 4 adult males, 19 yearlings and 8 juveniles) during Mar.-Oct. 2008 in $\sim 1200$ trapnights. Radio transmitters were implanted into 17 adults and three yearlings (13 F, $7 \mathrm{M})$. No females were lactating at capture, but three showed signs of recent suckling. At the end of field activities, we were monitoring two telemetered adults $(1 \mathrm{~F}, 1 \mathrm{M})$ and six individuals were missing.

Survival.-We estimated survival from the monitoring of 20 telemetered woodchucks. Three of these individuals were initially transmittered as yearlings and ended the study as adults; therefore, we did not include age as a variable in our modeling. The top survival model contained sex as a factor (Table 1), with annual survival ( $\pm \mathrm{SE}$ ) estimates for males and females of $1.0 \pm 0.0$ and $0.68 \pm 0.15$, respectively. The sex model containing $\%$ urban landcover as a covariate was 2.04 AICc units greater than the top model. The sex*season and null models had weak support at 1.37 and $1.95 \Delta$ AICc units, respectively, greater than the top model. Overall annual survival of adult woodchucks was estimated to be $0.76 \pm 0.12$.

We recorded three mortalities, all of adult females. Two were believed to be depredated by large canids [coyote (Canis latrans) or domestic dog] and one transmitter began emitting on mortality mode at the end of the hibernation period. The mortality at the end of the hibernation period was the lone individual to move locations during the winter. This same individual had been earlier translocated by a human resident. Most surviving females were recovered $(n=7)$, with others missing $(n=2)$ or being monitored at the end of the study $(\mathrm{n}=1)$. Two of the missing animals were likely trapped as nuisance animals. No male 


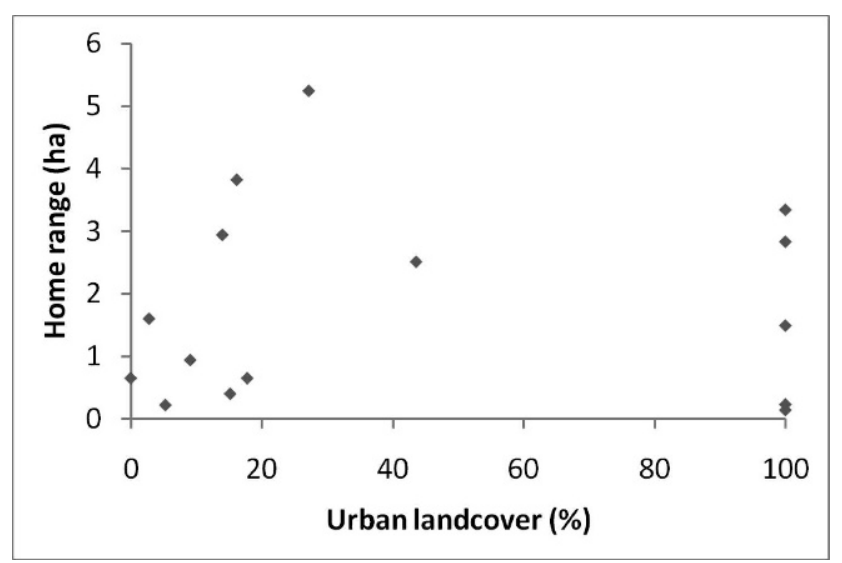

FIG. 1.-Plot of home-range size in woodchucks vs. \% urban landcover contained within a 500-mradius buffer surrounding the animal's capture location in the greater Carbondale, Illinois area

mortalities were noted, although four individuals were missing. The other three males had been recovered $(n=2)$ or were still being monitored $(n=1)$ at the end of the project monitoring period.

Home range and habitat selection. - We estimated home ranges for 16 individuals with 10-57 relocations. These individuals were monitored for 79-596 d (total radiodays $=4425$ ). Home-range sizes ranged from 0.15 ha to 3.83 ha, and averaged $2.59( \pm 1.09, \mathrm{n}=4)$ ha for males and $1.53( \pm 0.39, \mathrm{n}=11)$ ha for females (Fig. 1). The home-range size of a single relocated female (14.83 ha) was considered an outlier and not included in the average due to large movements immediately after the relocation and again before hibernation. There was no relationship $\left(\mathrm{F}_{1,12}=0.25, \mathrm{P}=0.63\right)$ between home-range size and $\%$ urban landcover in a buffer surrounding the capture locations of study woodchucks (Fig. 1).

We collected 439 radiolocations on 16 woodchucks for analysis of habitat selection. There was no overall second-order $(\lambda=0.382, \mathrm{P}=0.132)$ or third-order $(\lambda=0.363, \mathrm{P}=0.108)$ habitat selection when considering all defined types of landcover (Table 2). However, there were significant pairwise differences between some types of landcover (Table 3). When landcover types were pooled into four types (urban, rural, urban-edge and rural-edge), overall second-order selection was marginally significant $(\lambda=0.596, \mathrm{P}=0.058)$. Rural edge

TABLE 2.- Summary of landcover types within 500-m-radius buffers around home ranges, within home ranges, and by telemetry locations within home ranges for woodchucks $(\mathrm{n}=16)$ in southern Illinois, 2008-2009

\begin{tabular}{|c|c|c|c|c|c|c|c|c|}
\hline \multirow[b]{2}{*}{ Scale } & \multicolumn{8}{|c|}{ \% Landcover type } \\
\hline & $\begin{array}{l}\text { Rural } \\
\text { edge }\end{array}$ & $\begin{array}{l}\text { Rural } \\
\text { forest }\end{array}$ & $\begin{array}{l}\text { Urban } \\
\text { edge }\end{array}$ & $\begin{array}{c}\text { Rural } \\
\text { agriculture }\end{array}$ & $\begin{array}{c}\text { Rural } \\
\text { open/ } \\
\text { grass }\end{array}$ & $\begin{array}{l}\text { Urban } \\
\text { forest }\end{array}$ & $\begin{array}{c}\text { Urban } \\
\text { open/ } \\
\text { grass }\end{array}$ & Developed \\
\hline \multicolumn{9}{|l|}{ Buffer } \\
\hline zones & $12.9 \pm 5.2$ & $24.8 \pm 6.5$ & $5.2 \pm 1.6$ & $6.3 \pm 2.4$ & $11.3 \pm 4.7$ & $6.5 \pm 2.9$ & $19.4 \pm 6.4$ & $13.8 \pm 3.2$ \\
\hline \multicolumn{9}{|c|}{ 皮 } \\
\hline ranges & $20.8 \pm 4.7$ & $30.9 \pm 7.3$ & $9.8 \pm 5.9$ & $2.7 \pm 1.6$ & $5.6 \pm 3.3$ & $5.9 \pm 5.2$ & $18.6 \pm 7.6$ & $6.1 \pm 1.7$ \\
\hline Locations & $30.8 \pm 6.5$ & $15.1 \pm 4.4$ & $14.2 \pm 7.1$ & $1.0 \pm 1.0$ & $2.5 \pm 1.8$ & $5.0 \pm 4.0$ & $14.3 \pm 6.0$ & $16.8 \pm 4.9$ \\
\hline
\end{tabular}


TABLE 3.- Matrices and habitat ranking from compositional analysis of habitat selection in woodchucks in southern Illinois, 2008-2009. The sign of the $t$-values for landcover comparisons is indicated with + or - signs; +++ and --- represent pairwise comparisons with $\mathrm{P}<0.05$. Comparisons are read as rows vs. columns (e.g., rural edge selected more than urban edge for second-order analysis)

\begin{tabular}{|c|c|c|c|c|c|c|c|c|}
\hline \multirow[b]{2}{*}{ Scale of analysis } & \multicolumn{8}{|c|}{ Landcover type } \\
\hline & $\begin{array}{l}\text { Rural } \\
\text { edge }\end{array}$ & $\begin{array}{l}\text { Rural } \\
\text { forest }\end{array}$ & $\begin{array}{l}\text { Urban } \\
\text { edge }\end{array}$ & $\begin{array}{c}\text { Rural } \\
\text { agriculture }\end{array}$ & $\begin{array}{c}\text { Rural } \\
\text { open/grass }\end{array}$ & $\begin{array}{l}\text { Urban } \\
\text { forest }\end{array}$ & $\begin{array}{c}\text { Urban } \\
\text { open/grass }\end{array}$ & Developed \\
\hline \multicolumn{9}{|l|}{ Second order } \\
\hline Rural edge & & + & +++ & +++ & +++ & +++ & +++ & +++ \\
\hline Rural forest & - & & + & +++ & +++ & +++ & +++ & +++ \\
\hline Urban edge & --- & --- & & + & +++ & +++ & +++ & +++ \\
\hline Rural agriculture & --- & --- & - & & + & +++ & +++ & +++ \\
\hline Rural open/grass & --- & --- & --- & - & & +++ & +++ & +++ \\
\hline Urban forest & --- & --- & --- & --- & --- & & + & + \\
\hline Urban open/grass & --- & --- & --- & --- & --- & - & & + \\
\hline Developed & --- & --- & --- & --- & --- & - & - & \\
\hline & \multicolumn{8}{|c|}{ Landcover type } \\
\hline Scale of analysis & Rural edge & Developed & $\begin{array}{c}\text { Urban } \\
\text { open/grass }\end{array}$ & $\begin{array}{l}\text { Rural } \\
\text { forest }\end{array}$ & $\begin{array}{l}\text { Urban } \\
\text { forest }\end{array}$ & $\begin{array}{l}\text { Urban } \\
\text { edge }\end{array}$ & $\begin{array}{c}\text { Rural } \\
\text { open/grass }\end{array}$ & $\begin{array}{c}\text { Rural } \\
\text { agriculture }\end{array}$ \\
\hline \multicolumn{9}{|l|}{ Third order } \\
\hline Rural edge & & + & +++ & +++ & +++ & +++ & +++ & +++ \\
\hline Developed & - & & +++ & +++ & +++ & +++ & +++ & +++ \\
\hline Urban open/grass & --- & --- & & + & + & +++ & +++ & +++ \\
\hline Rural forest & --- & --- & - & & + & + & +++ & +++ \\
\hline Urban forest & --- & --- & - & - & & + & +++ & +++ \\
\hline Urban edge & --- & --- & --- & - & - & & +++ & +++ \\
\hline Rural open/grass & --- & --- & --- & --- & --- & --- & & + \\
\hline Rural agriculture & --- & --- & --- & --- & --- & --- & - & \\
\hline
\end{tabular}

was the most highly ranked type and urban cover the lowest-ranked, with rural and urban edge not significantly different from each other. For the same categories of landcover, there was strong third-order selection $(\lambda=0.395, \mathrm{P}=0.008)$. Urban was the most highly ranked landcover at this within-home-range scale. Note that developed landcover was selected relative to all other cover types except rural edge in the overall third-order analysis (Table 3). Finally, there was marginal selection for edge over non-edge landcover at both second- $(\lambda=0.814, \mathrm{P}=0.077)$ and third-order $(\lambda=0.798, \mathrm{P}=0.075)$ scales.

Body condition analysis. - Nine individuals were captured an average of $35 \mathrm{~d}$ (range: 12 $61 \mathrm{~d})$ after emergence from hibernation. These individuals were sacrificed to recover transmitters, iButtons and to obtain tissue samples. Kidney fat indices ranged from $8 \%$ to $35 \%$. Linear regression showed a marginal negative effect of $\%$ urban landcover on kidney fat index $\left(\mathrm{F}_{1,8}=5.18, \mathrm{P}=0.057\right.$; Fig. 2$)$. Similarly, regressing body condition index $\left(\mathrm{kg} / \mathrm{m}^{3}\right)$ on $\%$ urban land cover revealed a negative effect of urban landcover within an individual's home range on body condition $\left(\mathrm{F}_{1,8}=10.62, \mathrm{P}=0.014\right.$; Fig. 2).

The composition of adipose and muscle tissues differed $(\mathrm{P}<0.05)$ for nearly all individual fatty acids (Table 4). Generally, adipose tissue had higher percentages of monounsaturated fatty acids (particularly 18:1n-9, oleic acid) than muscle samples; whereas muscle samples had higher percentages of polyunsaturated fatty acids, such as 18:2n-6 


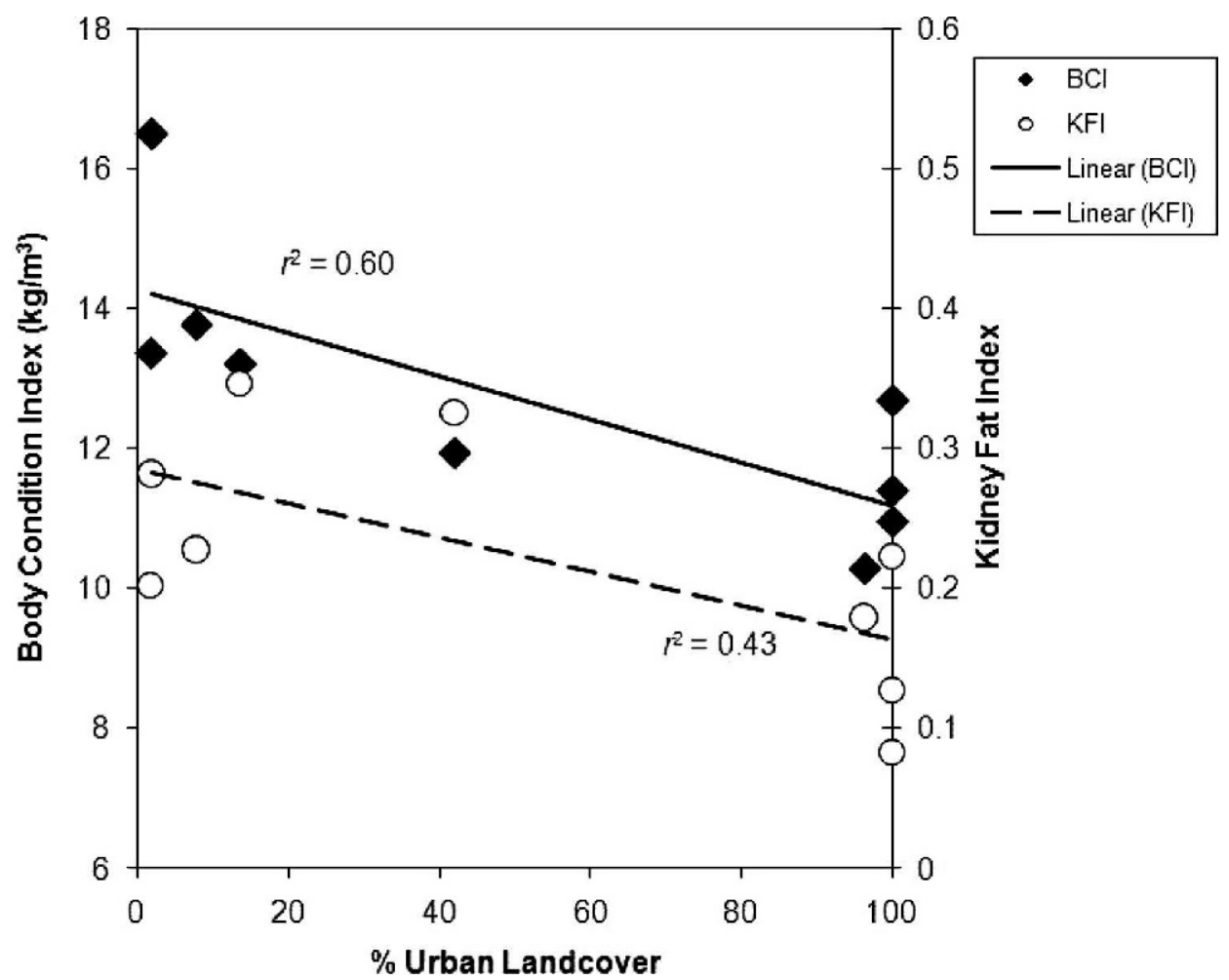

FIG. 2.-Regression of body condition index $\left(\mathrm{kg} / \mathrm{m}^{3}\right)$ and kidney fat index in woodchucks on $\%$ urban landcover within a 500-m-radius buffer surrounding capture point of corresponding woodchuck in the greater Carbondale, Illinois area

(linoleic acid) than adipose samples. If the Bonferroni-corrected $\alpha$ ( $\mathrm{P}<0.0017)$ is used, these patterns were retained, with nine (of 29) comparisons differing between fat and muscle samples (Table 4). Comparisons of urban vs. rural samples isolated only two marginal effects, with rural adipose samples having a higher percentage $(\mathrm{P}=0.06)$ of $18: 2 \mathrm{n}-$ 6 (linoleic acid) and rural muscle samples having a higher percentage $(P=0.09)$ of 18:3n-6 ( $\gamma$-linolenic acid) than corresponding urban samples. With the more conservative Bonferroni-corrected $\alpha$, none of these comparisons is close to significance.

\section{Discussion}

We detected no effect of urbanization level on woodchuck survival. This result was not surprising given the few mortalities $(\mathrm{n}=3)$ and overall high survival rate. Canid predation [likely coyotes (Canis latrans) or domestic dog] accounted for the only two known mortalities, with an additional unknown mortality during late hibernation. Predation by large carnivores is the dominant cause of mortality in other wildland populations of Marmota (Bryant and Page, 2005). Anthropogenic mortality in our population occurs based on numerous observations of road-killed individuals within the study area. In addition, we suspect that two missing woodchucks were likely trapped by landowners as nuisance animals. Unfortunately, our limited sample did not allow assessment of the magnitude of 
TABLE 4.-Fatty acid composition (\%) of muscle and adipose samples from woodchucks collected in southern Illinois, 18 Mar.-13 Apr. 2009 (<60 d after emergence)

\begin{tabular}{|c|c|c|c|c|c|c|c|c|}
\hline \multirow[b]{3}{*}{ Fatty acid } & \multicolumn{4}{|c|}{ Adipose tissue } & \multicolumn{4}{|c|}{ Muscle tissue } \\
\hline & \multicolumn{2}{|c|}{ Urban $(\mathrm{n}=3)$} & \multicolumn{2}{|c|}{ Rural $(\mathrm{n}=4)$} & \multicolumn{2}{|c|}{ Urban $(\mathrm{n}=4)$} & \multicolumn{2}{|c|}{ Rural $(\mathrm{n}=3)$} \\
\hline & Mean & $\mathrm{SE}$ & Mean & $\mathrm{SE}$ & Mean & $\mathrm{SE}$ & Mean & SE \\
\hline $14: 0^{* * *}$ & 1.49 & 0.08 & 1.30 & 0.14 & 0.90 & 0.22 & 0.87 & 0.07 \\
\hline $14: 1$ & 0.09 & 0.05 & 0.02 & 0.02 & 0.05 & 0.05 & 0.00 & 0.00 \\
\hline $15: 0$ & 0.17 & 0.09 & 0.10 & 0.06 & 0.03 & 0.03 & 0.05 & 0.05 \\
\hline 16:0 & 14.77 & 0.92 & 14.78 & 0.25 & 16.10 & 0.29 & 15.64 & 0.89 \\
\hline $16: 1$ & 2.69 & 0.42 & 1.84 & 0.45 & 2.00 & 0.55 & 1.74 & 0.09 \\
\hline $17: 0$ & 0.71 & 0.10 & 0.50 & 0.17 & 0.71 & 0.07 & 0.59 & 0.04 \\
\hline $16: 3$ & 0.17 & 0.17 & 0.00 & 0.00 & 0.00 & 0.00 & 0.00 & 0.00 \\
\hline $18: 0^{* * *}$ & 3.12 & 0.96 & 4.36 & 0.94 & 9.16 & 1.98 & 7.63 & 1.00 \\
\hline $18: \ln -9^{* * * *}$ & 55.15 & 2.89 & 54.51 & 1.89 & 28.44 & 7.63 & 33.24 & 5.04 \\
\hline $18: \ln -7^{* *}$ & 1.00 & 0.18 & 0.94 & 0.15 & 1.57 & 0.17 & 1.30 & 0.18 \\
\hline $18: 2 n-6^{* * * *}$ & 6.34 & 0.28 & 9.58 & 1.10 & 19.98 & 3.86 & 19.28 & 1.34 \\
\hline $18: 3 n-6^{*}$ & 0.00 & 0.00 & 0.11 & 0.04 & 0.12 & 0.01 & 0.19 & 0.04 \\
\hline $18: 3 n-4$ & 0.00 & 0.00 & 0.00 & 0.00 & 0.07 & 0.07 & 0.00 & 0.00 \\
\hline $18: 3 n-3$ & 13.63 & 2.94 & 10.95 & 2.23 & 7.00 & 2.14 & 9.57 & 1.08 \\
\hline $20: 0$ & 0.05 & 0.05 & 0.21 & 0.08 & 0.06 & 0.04 & 0.12 & 0.01 \\
\hline $20: 1^{* * *}$ & 0.57 & 0.15 & 0.64 & 0.11 & 0.30 & 0.04 & 0.37 & 0.02 \\
\hline $20: 2$ & 0.00 & 0.00 & 0.00 & 0.00 & 0.06 & 0.04 & 0.00 & 0.00 \\
\hline $20: 3$ & 0.00 & 0.00 & 0.00 & 0.00 & 0.08 & 0.08 & 0.00 & 0.00 \\
\hline $20: 4 n-6^{* * * *}$ & 0.03 & 0.03 & 0.05 & 0.05 & 6.86 & 2.20 & 5.13 & 1.00 \\
\hline $20: 5 n-3^{* * * *}$ & 0.00 & 0.00 & 0.00 & 0.00 & 1.05 & 0.29 & 0.69 & 0.22 \\
\hline $22: 5^{* * * *}$ & 0.00 & 0.00 & 0.11 & 0.11 & 3.76 & 1.29 & 2.57 & 0.56 \\
\hline $22: 6 n-3^{* * *}$ & 0.00 & 0.00 & 0.00 & 0.00 & 1.45 & 0.48 & 0.79 & 0.27 \\
\hline $24: 1^{* * * *}$ & 0.00 & 0.00 & 0.00 & 0.00 & 0.21 & $\begin{array}{l}0.70 \\
0.08\end{array}$ & 0.21 & 0.04 \\
\hline Total saturated FA** & 20.31 & 0.62 & 21.25 & 1.44 & 26.97 & 2.03 & 24.91 & 1.91 \\
\hline \multicolumn{9}{|l|}{ Total monounsaturated } \\
\hline $\mathrm{FA}^{* * *}$ & 59.50 & 2.99 & 57.95 & 2.40 & 32.57 & 8.01 & 36.87 & 4.98 \\
\hline Total polyunsaturated $\mathrm{FA}^{* * * *}$ & 20.18 & 3.17 & 20.80 & 3.15 & 40.46 & 6.01 & 38.22 & 3.15 \\
\hline $\mathrm{n}-6 \mathrm{FA}^{* * * *}$ & 6.38 & 0.31 & 9.74 & 1.14 & 27.11 & 6.04 & 24.60 & 2.34 \\
\hline n-3 FA & 13.63 & 2.94 & 11.05 & 2.16 & 13.29 & 0.61 & 13.62 & 1.25 \\
\hline$n-3: n-6^{* * *}$ & 2.13 & 0.45 & 1.12 & 0.15 & 0.58 & 0.15 & 0.56 & 0.05 \\
\hline
\end{tabular}

${ }^{* * * *} \mathrm{P}<0.001,{ }^{* * *} \mathrm{P}<0.01,{ }^{*} \mathrm{P}<0.05$ (Comparisons between adipose and tissue samples)

anthropogenic mortality. Survival rates of wildlife species can be higher or lower in urban environments, depending on such variables as food availability, predator densities and direct human mortality (Ditchkoff et al., 2006). For example, predation by domestic carnivores on small mammals may be greater in the urban-rural edge than in urban core areas (Gillies and Clout, 2003). For woodchucks, human harvest and predation may be greater in rural areas and vehicle collision and nuisance trapping may be greater in urban areas. However, adequate examination of the relative impact of these factors on our study species across the urban-rural gradient at the population level awaits larger samples.

The overall annual survival rate of 0.76 for adult woodchucks in southern Illinois is similar in magnitude to survival rates of several other species of Marmota. Survival of adult female yellow-bellied marmots ( $M$. flaviventris) in Colorado varied by site from 0.62 to 0.80 (Ozgul et $a l ., 2006)$, with an average of 0.76 in established colonies. Estimates of annual survival in two 
endangered species, Olympic marmots ( $M$. olympus) and Vancouver marmots ( $M$. vancouverensis), were 0.69 and 0.79 for adult females and adult males, respectively, in the former species (Griffin et al., 2008); and 0.79 and 0.74 for adult females and adult males, respectively, in the latter species (Bryant and Page, 2005). Olympic and Vancouver marmots are both declining, perhaps due to decreases in adult female survival (Griffin et al., 2008). However, the similarity in survival rates between these endangered species and our study population is not necessarily evidence that woodchucks in southern Illinois are declining. Woodchucks have larger litter sizes (average $=4.67$; Hayssen, 2008) than the endangered marmots (3.4-4.0; Hayssen, 2008), and this demographic characteristic may permit woodchuck populations to remain stationary at lower adult survival rates than the other species.

Home-range sizes and spatial organization in woodchucks vary considerably across time and space (see references in Maher, 2004), and are believed to be linked to variation in resource distribution and abundance (Swihart, 1992; Maher, 2004). The lack of any relationship between home-range size and urbanization level suggested no clear link between urbanization and resource distribution, although our lack of data in the 50-90\% range of urban landscapes may have prevented us from observing a nonlinear (e.g., quadratic) relationship. Home-range sizes of woodchucks in our study population were comparable to those seen in two Connecticut orchards, where male and female ranges averaged 4.01 and 1.96 ha, respectively (minimum convex polygon; Swihart, 1992). Meier (1992) reported summer range sizes, also estimated with convex polygons, of 1.35 ha for females and 1.61 ha for males in a mixture of woodland and old-field habitats in southeastern Ohio. Males typically have larger ranges than females (Swihart, 1992; Maher, 2004).

Habitat selection by woodchucks across the urban gradient was consistent with their characterization as a "forest-edge species" (Armitage, 2003). Throughout their range, woodchucks occupy meadow hedgerows and openlands (e.g., pastures, old fields) interspersed with patches of forest (Armitage, 2003). Although we did not detect significant selection at the second-order level (selection of home ranges within a larger buffered area), all rural landcover types ranked higher than urban types except for urban edge. When the analysis was conducted on pooled types, rural edge emerged as the most highly ranked type at the second-order level, similar to findings by Swihart (1992) in orchard habitat in Connecticut.

The selection for urban cover at the third-order level may be driven by a within-home range preference for developed areas or, more specifically, human-built structures. The lack of second-order preference for any urban type of landcover, other than urban edge, suggests structures and other developed landcover do not influence selection of a home range by woodchucks. However, the finding that urban cover was the most preferred type at the third-order level suggested that individuals take advantage of usable shelter located within their home range. For instance, the home range of one individual comprised 9\% developed landcover, which was composed of road/driveway surface, a house and several barns. However, $62 \%$ of the locations for the individual were on developed landcover (mostly under one barn). Other individuals in mostly rural areas also had burrow locations under sheds, in trailers and around other structures.

Body-condition and physiological data provided some interesting avenues for future research on urban-rural comparisons in mammals. Although we only assessed nine individuals for body condition, both indices indicated better condition (greater KFI and BCI) in rural woodchucks after emergence from hibernation. In addition, adipose tissue 
from rural woodchucks had a higher percentage of linoleic acid, which is a key polyunsaturated fatty acid (PUFA) found in grains and seeds. We note that body condition and lipid composition were likely affected by food consumed after emergence because animals were sampled an average of $35 \mathrm{~d}$ after emergence. Future work should employ larger samples to provide better support for this finding, then focus on alternative explanations for variation in body composition between urban and rural individuals. Alternatives include differential food composition and availability, or variability in chronic stressors such as harassment.

Linoleic and linolenic acid, another PUFA, are considered essential fatty acids because they cannot be synthesized by mammals and therefore must be obtained in the diet (Florant, 1998). High levels of PUFA are generally believed to conserve membrane fluidity at low body temperatures because PUFA have lower melting points than saturated fatty acids (Munro and Thomas, 2004). Herbivorous hibernating mammals appear to regulate dietary intake of PUFA to a particular target, perhaps to optimize the hibernation process (too-high PUFA levels in fat depots may increase susceptibility to auto-oxidation; Munro and Thomas, 2004). Use of internal temperature data collected by iButtons to evaluate PUFA effects on the hibernation process would be a worthwhile approach; unfortunately, our thermal data were too sparse to conduct this evaluation.

Hibernating animals consuming diets higher in PUFA, particularly linoleic acid, tend to have longer bouts of hibernation and lower metabolic rates (Florant, 1998; Munro and Thomas, 2004), leading to overall energy conservation. Free-ranging alpine marmots (Marmota marmota) with the highest PUFA content in adipose tissue before hibernation lost the least mass overwinter (Bruns et al., 2000 cited in Munro and Thomas, 2004). If woodchuck survival varies along the urban-rural gradient, one possible mechanism for differences in overwinter survival may be variation in availability of PUFA-rich food items throughout the rural-urban mosaic.

Overall, our findings did not support predictions for woodchuck ecology if the species were synanthropic, directly benefiting from human activities and resources. Indeed, our pilot physiological data suggest the opposite. Survival rates and home-range sizes showed no relationship to urbanization level. However, woodchucks were confirmed to be urbanadapters, as described in McKinney (2002). Based on habitat rankings, they preferred home ranges composed of rural edge landcover; yet within those same home ranges, they selected human structures regardless of location along the urbanization gradient.

Acknowledgments. - This project was funded by Federal Aid Project W-150-R-1 administered through the Illinois Department of Natural Resources with the essential assistance of R. Bluett. We thank K. Lippmann and N. Alexander for help with field work, and J. Trushenski and J. Laporte for assistance with lipid analyses. Several private landowners provided access to land for trapping and monitoring woodchucks. We also thank two anonymous reviewers and Associate Editor M. Cramer for their constructive comments and suggestions.

\section{Literature Cited}

Aebischer, N. J., P. A. Robertson and R. E. Kenward. 1993. Compositional analysis of habitat use from animal radio-tracking data. Ecology, 74:1313-1325.

Armitage, K. B. 2003. Marmots, p. 188-210. In: G. A. Feldhamer, B. C. Thompson and J. A. Chapman (eds.). Wild mammals of North America: biology, conservation, and management. Second edition. Johns Hopkins University Press, Baltimore, Maryland.

Beiglbock, C. And W. Zenker. 2003. Evaluation of 3 combinations of anesthetics for use in free-ranging alpine marmots (Marmota marmota). J. Wildl. Dis., 39:665-674. 
Bruns, U., F. Frey-Roos, S. Pudritz, F. Tataruch, T. Ruf and W. Arnold. 2000. Essential fatty acids: their impact on free-living alpine marmots (Marmota marmota), p. 215-222. In: G. Heldmaier and M. Klingenspor (eds.). Life in the cold. Eleventh Internat. Hibernation Symp., Springer, Jungholz.

Bryant, A. A. ANd R. E. Page. 2005. Timing and causes of mortality in the endangered Vancouver Island marmot (Marmota vancouverensis). Can. J. Zool., 83:674-682.

Christie, W. W. 1982. Lipid analysis, 2nd ed. Pergamon, Oxford, UK.

DAVIS, D. E. 1964. Evaluation of characters for determining age of woodchucks. J. Wildl. Manage, 28:9-15.

Ditchkoff, S. S., S. T. SaAlfeld and C. J. Gibson. 2006. Animal behavior in urban ecosystems: Modifications due to human-induced stress. Urban Ecosyst., 9:5-12.

Florant, G. L. 1998. Lipid metabolism in hibernators: The importance of essential fatty acids. Am. Zool., 38:331-340.

Folch, J., M. Lees and G. H. Sloane-Stanley. 1957. A simple method for the isolation and purification of total lipids from animal tissues. J. Biol. Chem., 276:497-507.

Gehrt, S. E., C. Anchor and L. A. White. 2009. Home range and landscape use of coyotes in a metropolitan landscape: conflict or coexistence? J. Mammal., 90:1145-1158.

Gillies, C. And M. Clout. 2003. The prey of domestic cats (Felis catus) in two suburbs of Auckland City, New Zealand. J. Zool., 259:309-315.

Griffin, S. C., M. L. Taper, R. Hoffman and L. S. Mills. 2008. The case of the missing marmots: Are metapopulation dynamics or range-wide declines responsible? Biol. Conser., 141:1293-1309.

Hayssen, V. 2008. Reproductive effort in squirrels: ecological, phylogenetic, allometric, and latitudinal patterns. J. Mammal., 89:582-606.

Hooge, P. N. and B. Eichenlaub. 1997. Animal movement extension to ArcView (version 1.1). Alaska Biological Science Center, United States Geological Survey, Anchorage, Alaska.

Johnson, D. H. 1980. The comparison of usage and availability measurements for evaluating resource preference. Ecology, 61:65-71.

Kernohan, B. J., R. A. Gitzen and J. J. Millspaugh. 2001. Analysis of animal space use and movements, p. 125-166. In: J. J. Millspaugh and J. M. Marzluff (eds.). Radio tracking and animal populations. Academic Press, San Diego, California.

MAHER, C. R. 2004. Intrasexual territoriality in woodchucks (Marmota monax). J. Mammal., 85:1087-1094.

McKinney, M. L. 2002. Urbanization, biodiversity, and conservation. BioScience, 52:883-890.

MeIER, P. T. 1992. Social organization of woodchucks. Behav. Ecol. Sociobiol., 31:393-400.

Munro, D. And D. W. Thomas. 2004. The role of polyunsaturated fatty acids in the expression of torpor by mammals: a review. Zoology, 107:29-48.

Ozgul, A., K. B. Armitage, D. T. Blumstein and M. K. Oli. 2006. Spatiotemporal variation in survival rates: implications for population dynamics of yellow-bellied marmots. Ecology, 87:1027-1037.

Pollock, K. H., S. R. Winterstein, C. M. Bunck and P. D. Curtis. 1989. Survival analysis in telemetry studies: the staggered entry design. J. Wildl. Manage., 53:7-15.

RANDA, L. A. AND J. A. Yunger. 2006. Carnivore occurrence along an urban-rural gradient: a landscapelevel analysis. J. Mammal., 87:1154-1164.

Riney, T. 1955. Evaluating condition of free-ranging red deer (Cervus elaphus), with special reference to New Zealand. N. Z. J. Sci.Tech., 36B:429-463.

Snyder, R. L. and J. J. Christian. 1960. Reproductive cycle and litter size of the woodchuck. Ecology, 41:647-656.

SWIHART, R. K. 1992. Home-range attributes and spatial structure of woodchuck populations. J. Mammal., 73:604-618.

- AND P. M. Picone. 1994. Damage to apple trees associated with woodchuck burrows in orchards. J. Wildl. Manage., 58:357-360.

White, G. C. AND K. P. Burnham. 1999. Program MARK: survival estimation from populations of marked animals. Bird Study Suppl., 46:120-138. 